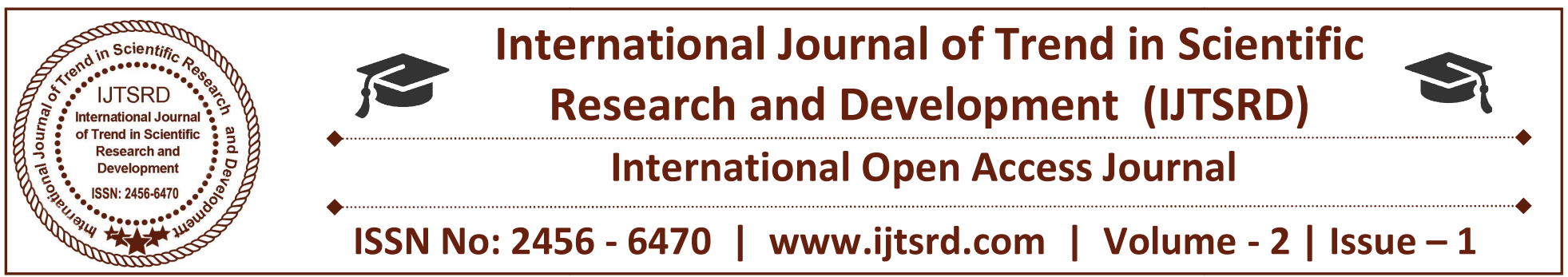

\title{
Problems Faced by the Farmers while Availing the Loan Facilities from the Banks - A Case Study of District Kulgam, Jammu and Kashmir
}

\author{
Mohd Asif Shah \\ Doctor of Philosophy (Ph.D.) in Economics, \\ Annamalai University, Tamil Nadu, India
}

\section{ABSTRACT}

Crop diversification refers to the addition of new crops or cropping systems to agricultural production on a particular farm taking into account the different returns from value-added crops with complementary marketing opportunities. It is an important mechanism for economic growth, which can be facilitated by technological breaks-through, by changes in consumer demand or in government policy or in trade arrangements, and by development of irrigation, roads, and other infrastructures. Diversification in agriculture is key in achieving food security, improved human nutrition and increase in rural employment. In the past few decades, agricultural sector in the whole state of Jammu and Kashmir and particularly in the district of Kulgam has witnessed a heavy shift in the cropping pattern from food crops to non-food crops (cash-crops). The horticultural sector has been playing an important role in the State, largely by contributing to the State Economy and turns to be the source of livelihood for nearly thirtythree lakh people, but the paddy production on the other hand has shown an opposite trend. Paddy land is getting changed into the horticultural land, as the farmers find it to be more remunerative. Kulgam, which was once the major producer of rice in the State, and was known to be the "Rice Bowl of Kashmir", is now among the least producers of rice. Farmers witnessed that sticking only to the waterintensive crops proved to be non-beneficial and they willingly shifted to the cash crops, like: apple, almond, and walnut. In the present study, the researcher estimates the association between the different socioeconomic variables and the problems faced by the farmers while availing the loan at the household level in Kulgam, one of the districts of Jammu and Kashmir, and Chi Square test has been used to find out the association.

Keywords: Crops; Cropping Systems; irrigation; roads; infrastructure; crop diversification; Kulgam; Jammu and Kashmir

\section{Introduction:}

Crop Diversification is widely held to offer large scope for improving the economic feasibility of many farm businesses and in turn decreasing their dependence on the production of primary subsidised agricultural commodities. It can be understood as some kind of entrepreneurial activity on behalf of the farmer. Crop diversification can be helpful in creating best opportunities such as: changing consumer demand, changing demographics, export potential, adding value, changing marketing opportunities; but also has created threats like urbanization, risk, external threats, domestic policy threats, climate change, and food insecurity. In making decisions about the diversification, farmers need to consider whether income generated by new farm enterprises will be greater than the existing activities, with similar or less risk.

It is a best strategy to achieve the goals of development. It took the attention of policy makers in the country during the recent years. The approach envisages changes in production activities of farm 
sector, to adjust to changes in economic environment and to face the problems like unemployment and depletion of natural resources (Ramesh Chand, 1999). The main objective of this approach is to raise per capita income by means of opening of avenues for prolific employment opportunities in farm and nonfarm sectors and to make the economic growth broad and stable in the long-run (Amitabh Kundu, 2012). The success of the policy lies in the identification of the particular crop for the appropriate region-specific, diversification choices, establishment of physical and institutional infrastructure services and execution of suitable strategies.

Another feature of this approach is to prepare the farmers to grow excellent and profitable produce based on both demand and supply in the long run (Anjani Kumar et al., 2012). Diversification in cropping pattern is likely to save the disintegration of agriculture economy and environment of the study area. Crop diversification acquires extraordinary implication in this region because of the ecological and environmental problems and depletion of the natural resources. Crop diversification refers to the competition between the crops growing in a region. If there is eagerness in the competition, the higher will be the extent of crop diversification; and less important the competition, the better will be the trend in the direction of crop specialization (where emphasis is on one or two crops). Therefore crop diversification is an idea which is contradictory to crop specialization. The extent of crop diversification mainly depends on the geo climatic/socio-economic conditions and technological development in the area (Husain, 2000).

India is blessed with a varied set of regional, agronomic, ecological, climatic, social and economic attributes. As far the state of Jammu and Kashmir is concerned, it is totally different regarding all these features with the rest of the country. The economy of Jammu \& Kashmir principally depends on agriculture, having about one-third of its population engaged with this agriculture and allied sectors. The geography setup of the area is restricting the growth of paddy cultivation. The production of paddy is not increasing in proportion to the cost involved in the farming, so in this background of stagnation in paddy production, which is not able to raise the level of employment in the region, horticulture is a possible option for exploration. The area is blessed with the appropriate climatic zones for rising temperate, sub-tropical and tropical fruits throughout the whole year. These fruits are not only the supplement diet of the local people, but also appear to be the main item of export to other parts of India and rest of world (SP Sharma et al., 2011). Kulgam which famous for the rice productivity once used to be called as rice bowl of the Kashmir is now amongst the least producers of rice (A. N. Raina, 2012). Paddy land is getting converted into horticultural land as farmers seek to earn more revenue against horticultural products (Mohmad Iqbal Reshi et al., 2010). Farmers feel that sticking only to the water-intensive crops like paddy in times of waterscarcity might prove non-beneficial and they readily switch over to cash crops like apple, almond and walnuts (J\&K Govt. Report, 2012).

\section{Theoretical Perspective:}

There are two ways by which the farmers go for crop diversification; one is to go for substitution and second way is to go for expansion. In the former one the farmers go directly for substituting the crop by new one, and in latter the farmers can go by increasing the land area by bringing unwanted lands or by clearing the forests under cultivation. But mostly the farmers have adopted substitution method rather than the expansion method in the study area. There are lots of theories (Theory of Production and Costs, Prof. Schultz Theory of Transforming Traditional Agriculture) which discuss about the crop diversification in detail, but the present study has used the Theory of Profit Maximisation to understand the issue very well.

\section{Methodology:}

The researcher has made an attempt to examine the ground realities in the study area to devise a methodology and research design of the present study by going through the existing literature meticulously in the area of research. The present study is exploratory in nature, mainly based on the primary data collected from thorough field survey with structured interview schedule and the units of analyses being the household heads.

\section{Sampling Design:}

Among the three divisions (Jammu, Kashmir, and Ladakh) of Jammu and Kashmir State, Kashmir division chosen for the present study which is dominated by the cultivation of apple. Kashmir division if further divided into South, North and Central parts, comprises of ten districts. Anantnag, 
Kulgam, Shopian, and Pulwama form the Southern part; while as Bandipora, Baramulla, and Kupwara forms the Northern part and Budgam, Ganderbal and Srinagar as the Central part of the region.

In all the ten districts of Kashmir region, both apple and rice are extensively cultivated. Out of which, the five districts which come under high productivity group in case of both apple and rice production are: Kulgam, Budgam, Anantnag, Pulwama, and Baramulla. Kulgam district, which was once known as the "Rice Bowl of Kashmir" has been chosen for observing the rapid trend in the shifting of paddy cultivation towards the apple cultivation over the last few decades.

Primary data were obtained from the survey samples by adopting stratified random sampling method to choose the respondents from the selected villages, with the help of an interview schedule by implementing three-stage sampling procedure as follows:

Stage I: Selection of all ten horticultural blocks of district Kulgam. (Manzgam, Waripora, D.K. Marg, Kulgam, Arreh, Kadder, Qazigund, Devsar, Qaimoh, and Yaripora)

Stage II: Selection of thirty-four highly apple populated orchardist villages from all ten blocks by the number of villages in the respective blocks.

Stage III: Selection of total of 272 sample respondents of the total thirty-four villages, eight sample respondents from each village.

\section{Objectives:}

The following objectives were set for the present research:

1. To find out the association between the different socioeconomic variables and the problems faced by the farmers while availing the loan.

\section{Hypotheses:}

1. There is an association between the attribute (age) and the problems faced by the farmers while availing the loan.

2. There is no association between the attribute (gender) and the problems faced by the farmers while availing the loan.

3. There is an association between the attribute (educational qualification) and the problems faced by the farmers while availing the loan.
4. There is no association between the attribute (occupation) and the problems faced by the farmers while availing the loan.

5. There is an association between the attribute (family type) and the problems faced by the farmers while availing the loan.

6. There is an association between the attribute (family size) and the problems faced by the farmers while availing the loan.

7. There is an association between the attribute (land owned) and the problems faced by the farmers while availing the loan.

\section{Results and Discussion:}

The table 1 examines the association between the dependent variable i.e. the problems faced by the respondents while availing the loan from the banks (whether they face the problems always, or very often, or sometimes, or rarely, or never) and the various independent variables (characteristics of the household head) such as age, gender, educational qualification, occupation, family type, family size and land owned. Out of the total sample size, $\mathrm{N}=272$ respondents, 108 respondents (39.7 per cent) depicted that they face the problems only "sometimes", 74 respondents (27.2 per cent) are "rarely" facing the problems, 36 respondents (13.2 per cent) "very often" face the problems, 34 respondents (12.5 per cent) "never" face the problems and the rest of the 20 respondents (7.4 per cent) "always" faced the problem.

In the age group of 21 to 40 , the highest share of 28 sample respondents (58.3 per cent of the row total) faced the problem only sometimes, 4 sample respondents (8.3 per cent of the row total) always faced the problem and 4 sample respondents $(8.3$ per cent of the row total) never faced any problem. In the age group of 21 to 40 , the highest share of 66 sample respondents (38.4 per cent of the row total) faced the problem only sometimes, 24 sample respondents (14.0 per cent of the row total) never faced any problem and 14 sample respondents ( 8.1 per cent of the row total) always faced the problem. And in the age group of 21 to 40 , the highest share of 22 sample respondents (42.3 per cent of the row total) rarely faced the problem, 6 sample respondents (11.5 per cent of the row total) never faced any problem and 2 sample respondents (3.8 per cent of the row total) always faced the problem. 
The Chi Square test is used for finding out the association between the attribute (age) and the problems faced by the respondents while availing the loan from the banks. The result reveals that the calculated chi-square value (17.67) at 8 degrees of freedom is significant at 0.01 levels. Therefore, it can be concluded that there is an association between the attribute (age) and the problems faced by the respondents while availing the loan from the banks.

In the case of gender, among the males, the highest share of 98 sample respondents (40.2 per cent of the row total) faced the problem only sometimes, 28 sample respondents (11.5 per cent of the row total) never faced any problem and 20 sample respondents (8.2 per cent of the row total) always faced the problem, and among the females 10 sample respondents (35.7 per cent of the row total) faced the problem only sometimes, 10 sample respondents $(35.7$ per cent of the row total) rarely faced any problems, 6 sample respondents (21.4 per cent of the row total) never faced any problems and none of the respondents depicted the facing of problem always.

The Chi Square test is used for finding out the association between the attribute (gender) and the problems faced by the respondents while availing the loan from the banks. The result reveals that the calculated chi-square value (6.11) at 1 degrees of freedom is $>0.05$. Therefore, it can be concluded that there is no association between the attribute (gender) and the problems faced by the respondents while availing the loan from the banks.

In the case of educational qualification, considering illiterates, the highest share of 34 sample respondents (42.5 per cent of the row total) faced the problem only sometimes, 10 sample respondents $(12.5$ per cent of the row total) never faced any problem and 6 sample respondents (7.5 per cent of the row total) always faced the problem. Likewise, among the respondents who have studied up to middle, the highest share of 34 sample respondents (33.3 per cent of the row total) faced the problem only sometimes, 18 sample respondents (17.6 per cent of the row total) never faced the problem and 12 sample respondents (11.8 per cent of the row total) always faced the problem. Among the respondents, who have studied HSC, the highest share of 12 sample respondents (33.3 per cent of the row total) faced the problem only sometimes, 4 sample respondents (11.1 per cent of the row total) never faced any problem and none of the respondents always faced any problem. Similarly, among the respondents who have studied up to graduation, 8 sample respondents (36.4 per cent of the row total) faced the problem only sometimes, 8 sample respondents (36.4 per cent of the row total) rarely faced the problem, 2 sample respondents $(9.1$ per cent of the row total) never faced any problem and none of the respondents always faced any problem. Finally, among the sample respondents who have studied PG or above, the highest share of 20 sample respondents (62.5 per cent of the row total) faced the problem only sometimes, 2 sample respondents $(6.3$ per cent of the row total) always faced the problem and none of the respondents never faced any problems.

The Chi Square test is used for finding out the association between the attribute (education) and the problems faced by the respondents while availing the loan from the banks. The result reveals that the calculated chi-square value (32.27) at 16 degrees of freedom is significant at 0.01 levels. Therefore, it can be concluded that there is an association between the attribute (education) and the problems faced by the respondents while availing the loan from the banks.

In the case of occupational structure, among the respondents practicing agriculture, the highest share of 46 sample respondents (39.0 per cent of the row total) faced the problem only sometimes, 18 sample respondents (15.3 per cent of the row total) never faced any problem and 10 sample respondents $(8.5$ per cent of the row total) always faced the problem. Similarly, among the respondents having business as their main income generating source, the highest share of 30 sample respondents (36.6per cent of the row total) faced the problem only sometimes, 10 sample respondents (12.2 per cent of the row total) never faced any problem and 6 sample respondents $(7.3$ per cent of the row total) always faced the problem. Likewise, among the respondents who are in government service, the highest share of 32 sample respondents (44.4 per cent of the row total) faced the problem only sometimes, 6 sample respondents $(8.3$ per cent of the row total) never faced any problem and 4 sample respondents (5.6 per cent of the row total) always faced the problem.

The Chi Square test is used for finding out the association between the attribute (occupation) and the problems faced by the respondents while availing the loan from the banks. The result reveals that the calculated chi-square value (10.61) at 8 degrees of freedom is $>0.05$. Therefore, it can be concluded that there is no association between the attribute 
(occupation) and the problems faced by the respondents while availing the loan from the banks.

In the case of family type, among the nuclear type household families, the highest share of 78 sample respondents (40.2 per cent of the row total) faced the problem only sometimes, 26 sample respondents (13.4 per cent of the row total) never faced any problem and 18 sample respondents ( 9.3 per cent of the row total) always faced the problem, and among the joint family type households the highest share of 30 sample respondents (38.5 per cent of the row total) faced the problem only sometimes, 8 sample respondents (10.3 per cent of the row total) never faced any problem and 2 sample respondents (2.6 per cent of the row total) always faced the problem.

The Chi Square test is used for finding out the association between the attribute (family type) and the problems faced by the respondents while availing the loan from the banks. The result reveals that the calculated chi-square value (8.31) at 4 degrees of freedom is significant at 0.01 levels. Therefore, it can be concluded that there is an association between the attribute (family type) and the problems faced by the respondents while availing the loan from the banks.

In the case of family size, in the group of households having family size below 5, the highest share of 68 sample respondents (43.6 per cent of the row total) faced the problem only sometimes, 22 sample respondents (14.1 per cent of the row total) never faced any problem and 8 sample respondents (5.1 per cent of the row total) always faced the problem. Among the households in the group of 6-10 the highest share of 26 sample respondents (34.2 per cent of the row total) faced the problem only sometimes, 12 sample respondents ( 15.8 per cent of the row total) always faced the problem and 8 sample respondents (10.5 per cent of the row total) never faced any problem. And, among the households having the family size of above 10, the highest share of 14 sample respondents (35.0 per cent of the row total) faced the problem only sometimes, 14 sample respondents (35.0 per cent of the row total) rarely faced the problem, 4 sample respondents $(10.0$ per cent of the row total) never faced any problem and none of the respondents always faced the problem.

The Chi Square test is used for finding out the association between the attribute (family size) and the problems faced by the respondents while availing the loan from the banks. The result reveals that the calculated chi-square value (17.54) at 8 degrees of freedom is significant at 0.01 levels. Therefore, it can be concluded that there is an association between the attribute (family size) and the problems faced by the respondents while availing the loan from the banks.

In case of land owned, considering the group of households having land size below 2 Kanals, the highest share of 4 sample respondents (40.0 per cent of the row total) faced the problem only sometimes, 6 sample respondents (60.0 per cent of the row total) rarely faced any problem and there was not any respondent left with other options. Among the respondents who are having the land size of 3 to 4 Kanals the highest share of 18 sample respondents (36.0 per cent of the row total) faced the problem only sometimes, 10 sample respondents $(20.0$ per cent of the row total) never faced any problem and 6 sample respondents (12.0 per cent of the row total) always faced the problem. Among the respondents, who have land size of 5 to 8 Kanals, the highest share of 42 sample respondents (38.9 per cent of the row total) faced the problem only sometimes, 12 sample respondents (11.1 per cent of the row total) always faced the problem and 10 sample respondents $(9.3$ per cent of the row total) never faced any problem. Among the respondents who have land size of 9 to 16 Kanals, the highest share of 44 sample respondents (47.8 per cent of the row total) faced the problem only sometimes, 14 sample respondents (15.2 per cent of the row total) never faced any problem and 2 sample respondents (2.2 per cent of the row total) always faced the problem. And among the sample respondents who have land size of above 16 Kanals, the highest share of 8 sample respondents (66.7 per cent of the row total) rarely faced the problem, 4 sample respondents (33.3 per cent of the row total) very often faced any problem and there was none of the respondent left with other options.

The Chi Square test is used for finding out the association between the attribute (land owned) and the problems faced by the respondents while availing the loan from the banks. The result reveals that the calculated chi-square value (39.3) at 16 degrees of freedom is significant at 0.01 levels. Therefore, it can be concluded that there is an association between the attribute (land owned) and the problems faced by the respondents while availing the loan from the banks. 
International Journal of Trend in Scientific Research and Development (IJTSRD) ISSN: 2456-6470

\section{REFERENCES}

1. Hussain M. 2000. Systematic Geography of J\&K. New Delhi: Rawat Publication. 113-125.

2. Joshi, P.K., Ahok Gulati, P.S. Birthal and Laxmi Tewari. 2003. "Agricultural Diversification in South Asia: Patterns, Determinants and Policy Implication." International Food Policy Research Institute, Washington, D.C., U.S.A. MSSD Discussion paper No. 57.

3. Kumar, Anjani, Pramod Kumar and Alakh N.Sharma. 2012. "Crop Diversification in Eastern India: Status and Determinants". Indian Journal of Agricultural Economics. Vol. 67, No.4, Oct-Dec, pp. 600-616.

4. Kumar, Anjani, Pramod Kumar and Alakh N.Sharma. 2012. "Crop Diversification in Eastern India: Status and Determinants". Indian Journal of Agricultural Economics. 67(4): 600-616.

5. Kundu, Amitabh. 2006. "Changing Agrarian System and Rural Urban Linkages" In Handbbok of Agriculture in India, ed. Shovan Roy. 183-202. New Delhi: Oxford University Press.

6. Raina, A. N. 2012. Geography of Jammu \& Kashmir State. Pacca Danga, Jammu: Radha Krishan Anand \& Co.

7. Ramesh Chand. 1999. "Emerging Crisis in Punjab Agriculture: Severity and Options for Future", Economic and Political Weekly. 34(13): A2-A10.

8. Reshi, Mohmad Iqbal, Muzaffer Ahmad Malik and Vijay Kumar. 2010. "Assessment of Problems and Prospects of Apple Production and
Marketing in Kashmir Valley, India." Journal of Environmental Research and Development. Vol. 4, April-June.

9. Shah, Mohd Shah., and A. Anbuvel. (2016) "Cropping Pattern Change in Jammu \& KashmirA Case Study of District Kulgam." Golden Research Thoughts (GRT-IMRJ), 6(6): 1-8.

10. Shah, Mohd Shah., and A. Anbuvel. (2016) "Determinants Crop Diversification in Jammu \& Kashmir-A Case Study of District Kulgam." Indian Streams Research Journal (ISJR-IMRJ), 6(10): 70-77.

11. Singh, R. S. (2005). "Marketing of citrus fruits in Mid Hills of Jammu \& Kashmir.’In Prasad,

Jagdish, ed. Encyclopedia of Agricultural Marketing. New Delhi: Mittal Publications.

12. Swaminathan, M. S. Abdul Aziz Zargar, Anwar Alam and Nagendra Sharma. 2008. "Towards food secure Jammu, Kashmir and Ladakh”. Epiolgue, (13): 10-13.

\section{REPORTS}

1. Agricultural Production Department. (2012-13), Government of Jammu and Kashmir.

2. Government of Jammu and Kashmir. (2012-13), Digest of Statistics, Directorate of Economics and Statistics.

3. Ph.D. Research Bureau Compiled from National Horticulture Board. (2010-11), Government of India. 
International Journal of Trend in Scientific Research and Development (IJTSRD) ISSN: 2456-6470

Table 1: Association between the Socio-Economic Variables and the Problems Faced By the Farmers While Availing the Loan

\begin{tabular}{|c|c|c|c|c|c|c|c|}
\hline \multirow{2}{*}{\multicolumn{2}{|c|}{ Variables }} & \multicolumn{5}{|c|}{ Facing The Problems While Taking Loan From The Banks. } & \multirow{2}{*}{ Total } \\
\hline & & Always & Very Often & Sometimes & Rarely & Never & \\
\hline \multirow{4}{*}{$\frac{80}{4}$} & 21 to 40 & $\begin{array}{c}4 \\
(8.3)\end{array}$ & $\begin{array}{c}2 \\
(4.2)\end{array}$ & $\begin{array}{c}28 \\
(58.3)\end{array}$ & $10(20.8)$ & $\begin{array}{c}4 \\
(8.3)\end{array}$ & $\begin{array}{c}48 \\
(100.0)\end{array}$ \\
\hline & 41 to 60 & $\begin{array}{c}14 \\
(8.1)\end{array}$ & $\begin{array}{c}26 \\
(15.1)\end{array}$ & $\begin{array}{c}66 \\
(38.4)\end{array}$ & $42(24.4)$ & $\begin{array}{c}24 \\
(14.0)\end{array}$ & $\begin{array}{c}172 \\
(100.0)\end{array}$ \\
\hline & Above 60 & $\begin{array}{c}2 \\
(3.8)\end{array}$ & $\begin{array}{c}8 \\
(15.4)\end{array}$ & $\begin{array}{c}14 \\
(26.9)\end{array}$ & $22(42.3)$ & $\begin{array}{c}6 \\
(11.5) \\
\end{array}$ & $\begin{array}{c}52 \\
(100.0)\end{array}$ \\
\hline & Total & $\begin{array}{c}20 \\
(7.4)\end{array}$ & $\begin{array}{c}36 \\
(13.2)\end{array}$ & $\begin{array}{c}108 \\
(39.7)\end{array}$ & $74(27.2)$ & $\begin{array}{c}34 \\
(12.5)\end{array}$ & $\begin{array}{c}272 \\
(100.0)\end{array}$ \\
\hline \multicolumn{3}{|c|}{ Chi Square } & \multicolumn{3}{|c|}{ df } & \multicolumn{2}{|c|}{ P-Value } \\
\hline \multicolumn{3}{|c|}{17.67} & \multicolumn{3}{|c|}{8} & \multicolumn{2}{|c|}{$0.02 \mathrm{~S}$} \\
\hline \multirow{3}{*}{ 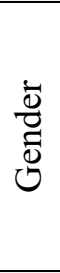 } & Male & $\begin{array}{c}20 \\
(8.2)\end{array}$ & $\begin{array}{c}34 \\
(13.9)\end{array}$ & $\begin{array}{c}98 \\
(40.2)\end{array}$ & $64(26.2)$ & $\begin{array}{c}28 \\
(11.5)\end{array}$ & $\begin{array}{c}244 \\
(100.0)\end{array}$ \\
\hline & Female & 0 & $\begin{array}{c}2 \\
(7.1) \\
\end{array}$ & $\begin{array}{c}10 \\
(35.7) \\
\end{array}$ & $10(35.7)$ & $\begin{array}{c}6 \\
(21.4) \\
\end{array}$ & $\begin{array}{c}28 \\
(100.0) \\
\end{array}$ \\
\hline & Total & $\begin{array}{c}20 \\
(7.4)\end{array}$ & $\begin{array}{c}36 \\
(13.2)\end{array}$ & $\begin{array}{c}108 \\
(39.7)\end{array}$ & $74(27.2)$ & $\begin{array}{c}34 \\
(12.5)\end{array}$ & $\begin{array}{c}272 \\
(100.0)\end{array}$ \\
\hline \multicolumn{3}{|c|}{ Chi Square } & \multicolumn{3}{|c|}{ df } & \multicolumn{2}{|c|}{ P-Value } \\
\hline \multicolumn{3}{|c|}{6.11} & \multicolumn{3}{|c|}{4} & \multicolumn{2}{|c|}{$0.19 \mathrm{NS}$} \\
\hline \multirow{6}{*}{ 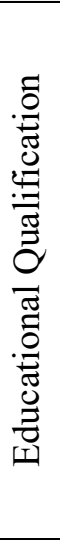 } & Illiterate & $\begin{array}{c}6 \\
(7.5)\end{array}$ & $\begin{array}{c}12 \\
(15.0)\end{array}$ & $\begin{array}{c}34 \\
(42.5)\end{array}$ & $\begin{array}{c}18 \\
(22.5)\end{array}$ & $\begin{array}{c}10 \\
(12.5)\end{array}$ & $\begin{array}{c}80 \\
(100.0)\end{array}$ \\
\hline & Middle & $12(11.8)$ & $\begin{array}{c}10 \\
(9.8)\end{array}$ & $\begin{array}{c}34 \\
(33.3)\end{array}$ & $\begin{array}{c}28 \\
(27.5)\end{array}$ & $\begin{array}{c}18 \\
(17.6)\end{array}$ & $\begin{array}{c}102 \\
(100.0)\end{array}$ \\
\hline & HSC & 0 & $\begin{array}{c}10 \\
(27.8)\end{array}$ & $\begin{array}{c}12 \\
(33.3)\end{array}$ & $\begin{array}{c}10 \\
(27.8)\end{array}$ & $\begin{array}{c}4 \\
(11.1) \\
\end{array}$ & $\begin{array}{c}36 \\
(100.0)\end{array}$ \\
\hline & Graduation & 0 & $\begin{array}{c}4 \\
(18.2) \\
\end{array}$ & $\begin{array}{c}8 \\
(36.4) \\
\end{array}$ & $\begin{array}{c}8 \\
(36.4) \\
\end{array}$ & $\begin{array}{c}2 \\
(9.1)\end{array}$ & $\begin{array}{c}22 \\
(100.0) \\
\end{array}$ \\
\hline & PG/other & $\begin{array}{c}2 \\
(6.3)\end{array}$ & 0 & $\begin{array}{c}20 \\
(62.5)\end{array}$ & $\begin{array}{c}10 \\
(31.3)\end{array}$ & 0 & $\begin{array}{c}32 \\
(100.0)\end{array}$ \\
\hline & Total & $\begin{array}{c}20 \\
(7.4)\end{array}$ & $\begin{array}{c}36 \\
(13.2)\end{array}$ & $\begin{array}{c}108 \\
(39.7)\end{array}$ & $\begin{array}{c}74 \\
(27.2)\end{array}$ & $\begin{array}{c}34 \\
(12.5)\end{array}$ & $\begin{array}{c}272 \\
(100.0)\end{array}$ \\
\hline \multicolumn{3}{|c|}{ Chi Square } & \multicolumn{3}{|c|}{$\mathrm{df}$} & \multicolumn{2}{|c|}{ P-Value } \\
\hline \multicolumn{3}{|c|}{32.27} & \multicolumn{3}{|c|}{16} & \multicolumn{2}{|c|}{$0.001 \mathrm{~S}$} \\
\hline \multirow{4}{*}{ 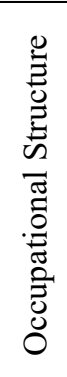 } & Agriculture & $\begin{array}{c}10 \\
(8.5)\end{array}$ & $\begin{array}{c}18 \\
(15.3)\end{array}$ & $\begin{array}{c}46 \\
(39.0)\end{array}$ & $\begin{array}{c}26 \\
(22.0)\end{array}$ & $\begin{array}{c}18 \\
(15.3)\end{array}$ & $\begin{array}{c}118 \\
(100.0)\end{array}$ \\
\hline & Business & $\begin{array}{c}6 \\
(7.3) \\
\end{array}$ & $\begin{array}{c}14 \\
(17.1)\end{array}$ & $\begin{array}{c}30 \\
(36.6) \\
\end{array}$ & $\begin{array}{c}22 \\
(26.8) \\
\end{array}$ & $\begin{array}{c}10 \\
(12.2) \\
\end{array}$ & $\begin{array}{c}82 \\
(100.0) \\
\end{array}$ \\
\hline & $\begin{array}{c}\text { Government } \\
\text { service }\end{array}$ & $\begin{array}{c}4 \\
(5.6)\end{array}$ & $\begin{array}{c}4 \\
(5.6)\end{array}$ & $\begin{array}{c}32 \\
(44.4)\end{array}$ & $\begin{array}{c}26 \\
(36.1)\end{array}$ & $\begin{array}{c}6 \\
(8.3)\end{array}$ & $\begin{array}{c}72 \\
(100.0)\end{array}$ \\
\hline & Total & $\begin{array}{c}20 \\
(7.4)\end{array}$ & $\begin{array}{c}36 \\
(13.2)\end{array}$ & $\begin{array}{c}108 \\
(39.7)\end{array}$ & $\begin{array}{c}74 \\
(27.2)\end{array}$ & $\begin{array}{c}34 \\
(12.5)\end{array}$ & $\begin{array}{c}272 \\
(100.0)\end{array}$ \\
\hline \multicolumn{3}{|c|}{ Chi Square } & \multicolumn{3}{|c|}{$\mathrm{df}$} & \multicolumn{2}{|c|}{ P-Value } \\
\hline \multicolumn{3}{|c|}{10.61} & \multicolumn{3}{|c|}{8} & \multicolumn{2}{|c|}{$0.22 \mathrm{NS}$} \\
\hline
\end{tabular}


Table 1 Contd...

\begin{tabular}{|c|c|c|c|c|c|c|c|}
\hline \multirow{2}{*}{\multicolumn{2}{|c|}{ Variables }} & \multicolumn{5}{|c|}{ Facing The Problems While Taking Loan From The Banks. } & \multirow{3}{*}{$\begin{array}{c}\text { Total } \\
194 \\
(100.0)\end{array}$} \\
\hline & & \multirow{2}{*}{$\begin{array}{c}\text { Always } \\
18 \\
(9.3)\end{array}$} & \multirow{2}{*}{$\begin{array}{c}\text { Very Often } \\
20 \\
(10.3)\end{array}$} & \multirow{2}{*}{$\begin{array}{c}\text { Sometimes } \\
78 \\
(40.2)\end{array}$} & \multirow{2}{*}{$\begin{array}{c}\text { Rarely } \\
52 \\
(26.8)\end{array}$} & \multirow{2}{*}{$\begin{array}{c}\text { Never } \\
26 \\
(13.4)\end{array}$} & \\
\hline$\stackrel{2}{\vec{z}}$ & Nuclear & & & & & & \\
\hline 离 & Joint & $\begin{array}{c}2 \\
(2.6)\end{array}$ & $\begin{array}{c}16 \\
(20.5)\end{array}$ & $\begin{array}{c}30 \\
(38.5)\end{array}$ & $\begin{array}{c}22 \\
(28.2)\end{array}$ & $\begin{array}{c}8 \\
(10.3)\end{array}$ & $\begin{array}{c}78 \\
(100.0)\end{array}$ \\
\hline 蛋 & Total & $\begin{array}{c}20 \\
(7.4)\end{array}$ & $\begin{array}{c}36 \\
(13.2)\end{array}$ & $\begin{array}{c}108 \\
(39.7)\end{array}$ & $74(27.2)$ & $\begin{array}{c}34 \\
(12.5)\end{array}$ & $\begin{array}{c}272 \\
(100.0)\end{array}$ \\
\hline \multicolumn{3}{|c|}{ Chi Square } & \multicolumn{3}{|c|}{ df } & \multicolumn{2}{|c|}{ P-Value } \\
\hline \multicolumn{3}{|c|}{8.31} & \multicolumn{3}{|c|}{4} & \multicolumn{2}{|c|}{$0.01 \mathrm{~S}$} \\
\hline \multirow{4}{*}{ 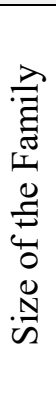 } & Below 5 & $\begin{array}{c}8 \\
(5.1) \\
\end{array}$ & $\begin{array}{c}16 \\
(10.3) \\
\end{array}$ & $\begin{array}{c}68 \\
(43.6) \\
\end{array}$ & $\begin{array}{c}42 \\
(26.9) \\
\end{array}$ & $\begin{array}{c}22 \\
(14.1) \\
\end{array}$ & $\begin{array}{c}156 \\
(100.0) \\
\end{array}$ \\
\hline & $6-10$ & $\begin{array}{c}12 \\
(15.8)\end{array}$ & $\begin{array}{c}12 \\
(15.8)\end{array}$ & $\begin{array}{c}26 \\
(34.2)\end{array}$ & $\begin{array}{c}18 \\
(23.7)\end{array}$ & $\begin{array}{c}8 \\
(10.5)\end{array}$ & $\begin{array}{c}76 \\
(100.0)\end{array}$ \\
\hline & Above 10 & 0 & $\begin{array}{c}8 \\
(20.0)\end{array}$ & $\begin{array}{c}14 \\
(35.0)\end{array}$ & $\begin{array}{c}14 \\
(35.0)\end{array}$ & $\begin{array}{c}4 \\
(10.0)\end{array}$ & $\begin{array}{c}40 \\
(100.0)\end{array}$ \\
\hline & Total & $\begin{array}{c}20 \\
(7.4)\end{array}$ & $\begin{array}{c}36 \\
(13.2)\end{array}$ & $\begin{array}{c}108 \\
(39.7)\end{array}$ & $74(27.2)$ & $\begin{array}{c}34 \\
(12.5)\end{array}$ & $\begin{array}{c}272 \\
(100.0)\end{array}$ \\
\hline \multicolumn{3}{|c|}{ Chi Square } & \multicolumn{3}{|c|}{ df } & \multicolumn{2}{|c|}{ P-Value } \\
\hline \multicolumn{3}{|c|}{17.54} & \multicolumn{3}{|c|}{8} & \multicolumn{2}{|c|}{$0.01 \mathrm{~S}$} \\
\hline \multirow{6}{*}{ 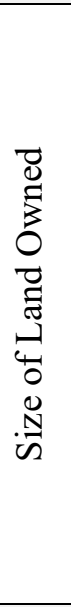 } & Below 2 & 0 & 0 & $\begin{array}{c}4 \\
(40.0) \\
\end{array}$ & $\begin{array}{c}6 \\
(60.0) \\
\end{array}$ & 0 & $\begin{array}{c}10 \\
(100.0)\end{array}$ \\
\hline & $3-4$ & $\begin{array}{c}6 \\
(12.0)\end{array}$ & $\begin{array}{c}6 \\
(12.0)\end{array}$ & $\begin{array}{c}18 \\
(36.0)\end{array}$ & $\begin{array}{c}10 \\
(20.0)\end{array}$ & $\begin{array}{c}10 \\
(20.0)\end{array}$ & $\begin{array}{c}50 \\
(100.0)\end{array}$ \\
\hline & $5-8$ & $\begin{array}{c}12 \\
(11.1)\end{array}$ & $\begin{array}{c}14 \\
(13.0)\end{array}$ & $\begin{array}{c}42 \\
(38.9)\end{array}$ & $\begin{array}{c}30 \\
(27.8)\end{array}$ & $\begin{array}{c}10 \\
(9.3)\end{array}$ & $\begin{array}{c}108 \\
(100.0)\end{array}$ \\
\hline & $9-16$ & $\begin{array}{c}2 \\
(2.2)\end{array}$ & $\begin{array}{c}12 \\
(13.0)\end{array}$ & $\begin{array}{c}44 \\
(47.8)\end{array}$ & $\begin{array}{c}20 \\
(21.7)\end{array}$ & $\begin{array}{c}14 \\
(15.2)\end{array}$ & $\begin{array}{c}92 \\
(100.0)\end{array}$ \\
\hline & Above 16 & 0 & $\begin{array}{c}4 \\
(33.3) \\
\end{array}$ & 0 & $\begin{array}{c}8 \\
(66.7) \\
\end{array}$ & 0 & $\begin{array}{c}12 \\
(100.0) \\
\end{array}$ \\
\hline & Total & $\begin{array}{c}20 \\
(7.4)\end{array}$ & $\begin{array}{c}36 \\
(13.2)\end{array}$ & $\begin{array}{c}108 \\
(39.7) \\
\end{array}$ & $\begin{array}{c}74 \\
(27.2)\end{array}$ & $\begin{array}{c}34 \\
(12.5) \\
\end{array}$ & $\begin{array}{c}272 \\
(100.0) \\
\end{array}$ \\
\hline \multicolumn{3}{|c|}{ Chi Square } & \multicolumn{3}{|c|}{ df } & \multicolumn{2}{|c|}{ P-Value } \\
\hline \multicolumn{3}{|c|}{39.30} & \multicolumn{3}{|c|}{16} & \multicolumn{2}{|c|}{$0.001 \mathrm{~S}$} \\
\hline
\end{tabular}

Source:Computed

Note: Figures in parentheses indicate percentage to the row total. 